\title{
Thermal history and comfort in a Brazilian subtropical climate: a 'cool' addiction hypothesis
}

\author{
Memória térmica e conforto em um clima subtropical \\ brasileiro: hipótese de vício ao resfriamento artificial
}

\section{Renata De Vecchi \\ Christhina Maria Cândido \\ Roberto Lamberts}

\begin{abstract}
$\mathbf{C}$

urrently, there is a rising trend for commercial buildings to use air conditioning to provide indoor thermal comfort. This paper focuses on the impact of prolonged exposure to indoor air-conditioned

environments on occupants' thermal acceptability and preferences in a mixed-mode building in Brazil. Questionnaires were administered while indoor microclimatic measurements were carried out (i.e., air temperature, radiant air temperature, air speed and humidity). Results suggest significant differences in occupants' thermal acceptability and cooling preferences based on thermal history; differences were found between groups based on different physical characteristics (i.e., different gender and body condition). The findings also indicated a significant potential to implement temperature fluctuations indoors when occupants are exposed to air conditioning environments in warm and humid climates.
\end{abstract}

Keywords: Thermal comfort. Thermal history. Mixed-mode buildings. Warm and humid climates.

\section{Resumo}

Atualmente, existe uma tendência crescente de edificações comerciais que utilizam o condicionamento artificial como forma de promover condições de conforto

Renata De Vecchi Universidade Federal de Santa Florianópolis - SC - Brasil

Christhina Maria Cândido The University of Sydney Sydney - Austrália

Roberto Lamberts Universidade Federal de Santa Catarina

Florianópolis - SC - Brasil

Recebido em 13/04/15 Aceito em 06/10/15 térmico. Este artigo foca no impacto causado pela exposição prolongada a ambientes condicionados artificialmente nos votos de aceitabilidade e preferência térmica de ocupantes em espaços condicionados de forma mista no Brasil. Questionários foram aplicados ao mesmo tempo em que variáveis microclimáticas internas foram medidas (temperatura do ar, temperatura radiante média, velocidade do ar e umidade relativa). Os resultados sugerem diferenças significativas na aceitabilidade térmica e preferência com base na memória térmica. Verificaram-se ainda diferenças entre grupos com diferentes características fisiológicas (sexo e massa corpórea). Os resultados apontam grande potencial para a implementação de flutuações de temperatura em grupos com exposição prévia ao condicionamento artificial em climas úmidos e razoavelmente quentes.

Palavras-chaves: Conforto térmico. Memória térmica. Sistemas mistos de condicionamento ambiental. Climas quentes e úmidos. 


\section{Introduction}

When it comes to providing comfort indoors, uniform environments with constant temperature conditions have become the norm. The rationale for this trend has been well researched and documented; with the most prominent body of work coming from Fanger's Predicted Mean Vote - the PMV model (FANGER, 1970). There is little dispute regarding Fanger's PMV model being the one that best predicts thermal comfort conditions indoors when driven by heating, ventilation and air conditioning systems (HVAC) (LINDEN; LOOMANS; HENSEN, 2008; HUMPHREYS; NICOL, 2010; AL-AJMI; LOVEDAY, 2010; CHOW et al., 2010). Later, the applicability of such model in naturally ventilated environments was challenged by de Dear and Brager's adaptive model (DE DEAR; BRAGER; COOPER, 1997). The basic principle of this model is that people adapt to indoor environmental conditions based on seasonal outdoor temperatures fluctuations. The authors argue that occupants would in fact, prefer such thermal variability experienced in naturally ventilated buildings. These results were later corroborated by many other researchers, which in turn has helped the acceptance and mainstream of the adaptive model (DE DEAR; BRAGER, 2002; FERIADI; WONG, 2004; ZHANG et al., 2010; MORS et al., 2011; CAO et al., 2011); INDRAGANTI; OOKA; RIJAL, 2013).

When predicting thermal acceptability indoors, the logic underlying the adaptive model aligns with the variety of temperature conditions people can be exposed to on a daily basis. Moreover, studies on thermal stimuli have so far indicated that the body can react positively to temperature fluctuations, and that these fluctuations can be linked to an individual thermal history (DE DEAR; AULICIEMS, 1988; CHUN et al., 2008; KWOK; RAJKOVICH, 2010; CÂNDIDO et al., 2010; PARKINSON; DE DEAR; CÂNDIDO, 2012). Thermal heterogeneity exposure can also be linked to occupants' health improvements and weight control (VAN MARKEN LICHTENBELT; SCHRAUWEN; WESTERTERP-PLANTEGA, 2001; JOHNSON et al., 2011), occupants' overall satisfaction with personal control systems (HUIZENGA; ZHANG; ARENS, 2001; TANABE et al., 2002; BRAGER; BAKER, 2009; BOERSTRA, 2010) and thermal pleasure (DE DEAR, 2011; CÂNDIDO; DEAR, 2012).

However, with most cars, office, stores, supermarkets and, more recently, houses resorting to air-conditioning to provide comfort indoors, people are spending more and more time in static indoor environments, and thus, this day-to-day thermal 'work-out' has been dramatically reduced (JOHNSON et al., 2011; KEITH et al., 2006). As such, there is little room for the adaptive model to be applied, and so far, PMV remains the primary way to predict thermal sensation in such conditions. This is a concern specially related to tropical regions such as Brazil and India, or developed nationals such as the United States, which are major markets for refrigeration and air conditioning.

But what happen when these two conditions meet and occupants are exposed to internal temperature fluctuations combined with the stability provided by air conditioned, such as the conditions found in mixed-mode buildings? And to which extend would prior prolonged exposure to a homogenous indoor environment (i.e., thermal history) influence occupants' thermal acceptability in mixed-mode buildings? This paper investigates these two questions, and focuses on the impact of prolonged exposure to static indoor environments on occupants' thermal acceptability and preferences in a mixed-mode building in Brazil.

\section{Method}

In order to answer the research questions of this paper, field campaigns were carried-out in classrooms of the Federal University of Santa Catarina during four months of 2010 (March, April, May and November). Two classrooms were measured at the Architecture and Planning Department based in a prerequisite: the existence of air-conditioning and ceiling fans that could operate simultaneously (Figure 1). Questionnaires were administered while indoor microclimatic measurements were carried out (i.e., air temperature, radiant air temperature, air speed and humidity), thus, the fundamental feature of the methodological design used in this study is the proximity - in time and space - of indoor climate observations with corresponding overall comfort votes from occupants in mixed-mode buildings.

\section{Measured environments}

The classrooms operate with a mixed-mode system combining active systems (air conditioning), mechanical ventilation (ceiling fans) and passive ventilation. When operated normally, these rooms offer adaptive opportunities to internal temperature maintenance such as opening windows and turning on/off ceiling fans and air conditioning. The first classroom was $63 \mathrm{~m}^{2}$, capacity for 56 students, a ceiling and wooden walls, windows positioned in the west wall and two window air conditioning

8 De Vecchi, R.; Cândido, C. M.; Lamberts, R. 
units (Figure 1, photo 01). The second classroom was located on the ground floor of a four-story building. The total area is $57 \mathrm{~m}^{2}$, with capacity for 42 students, brick walls, windows positioned in a south west orientation and one split air conditioning (Figure 1, photo 02). Both rooms have good conditions of natural lighting during the day and curtains to filter the sunlight, which were essentially controlled by the occupants.

\section{Climate}

Florianópolis is an island located on the southern coast of Brazil (latitude $27^{\circ} 40^{\prime} \mathrm{S}$ ), and according to Köppen's classification it represents a humid subtropical climate. The mean monthly temperature varies from 21 to $29^{\circ} \mathrm{C}$ during the summer time and from 13 and $22^{\circ} \mathrm{C}$ during the winter (GOULART; LAMBERTS; FIRMINO,
1998). Relative humidity is high throughout the year (minimum monthly average is $80 \%$ in November and maximum monthly average is $84 \%$ in July) and there is no dry season. The highest rainfall occurs from January to March and the lowest from July to August (mean annual precipitation is $1,521 \mathrm{~mm}$ ). The annual average global horizontal radiation in Florianópolis is 4.2 $\mathrm{kWh} / \mathrm{m}^{2}$ (PEREIRA et al., 2006). Regarding the winds direction, there is a higher prevalence in the northern direction, followed by the southern direction.

Table 1 shows the mean outdoor temperature acquired from a meteorological station located at the campus (Laboratory of Energy Conversion Engineering Technology - LEPTEN/UFSC) during the field study. This station provides data to the World Meteorological Organization (WMO).

Figure 1 - Satellite view from the buildings of Architecture and Planning Department with location and interior view of the measured environments
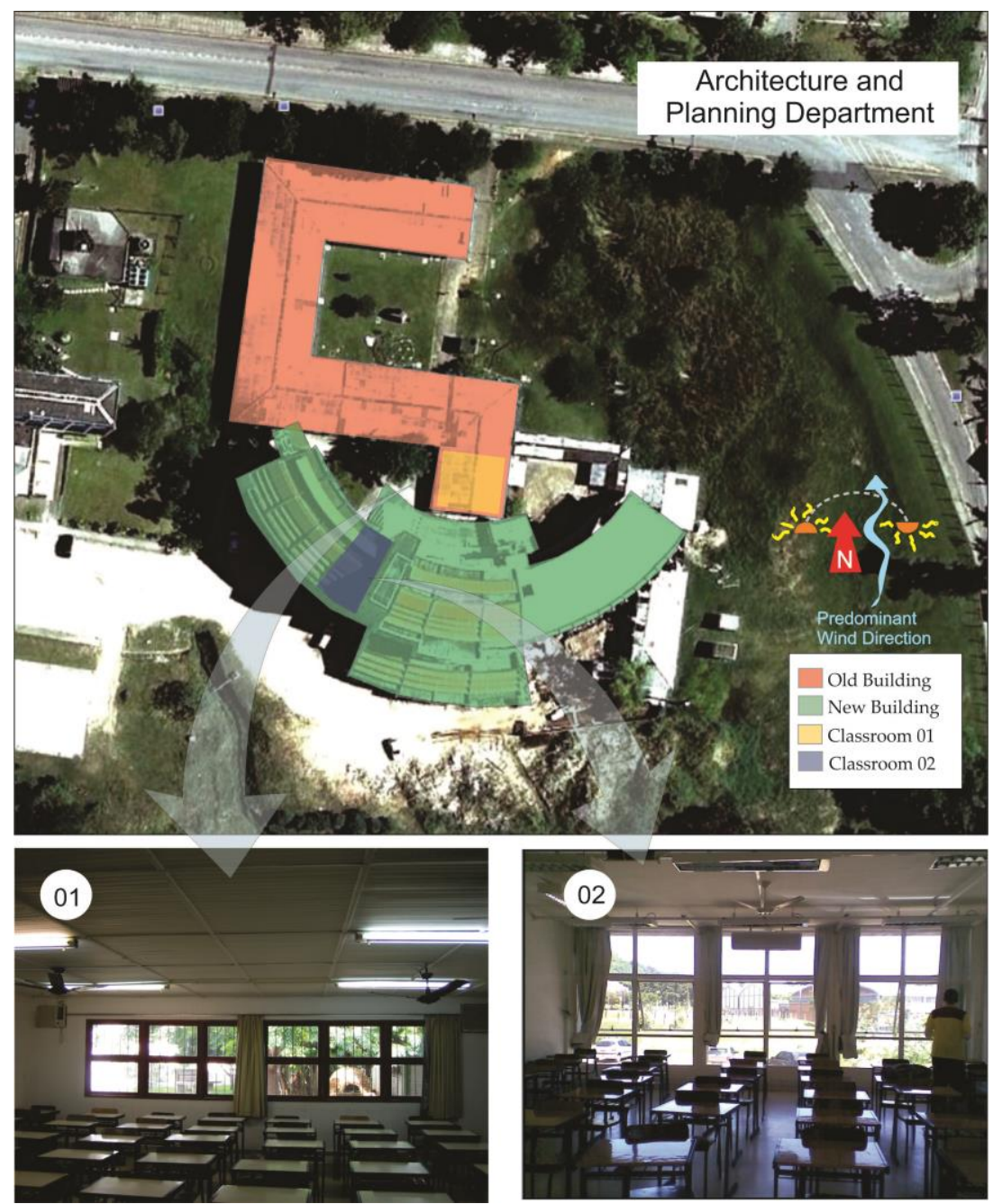
Figure 2 -Microclimatic Station (a) and Handheld hot-wire anemometer (b)
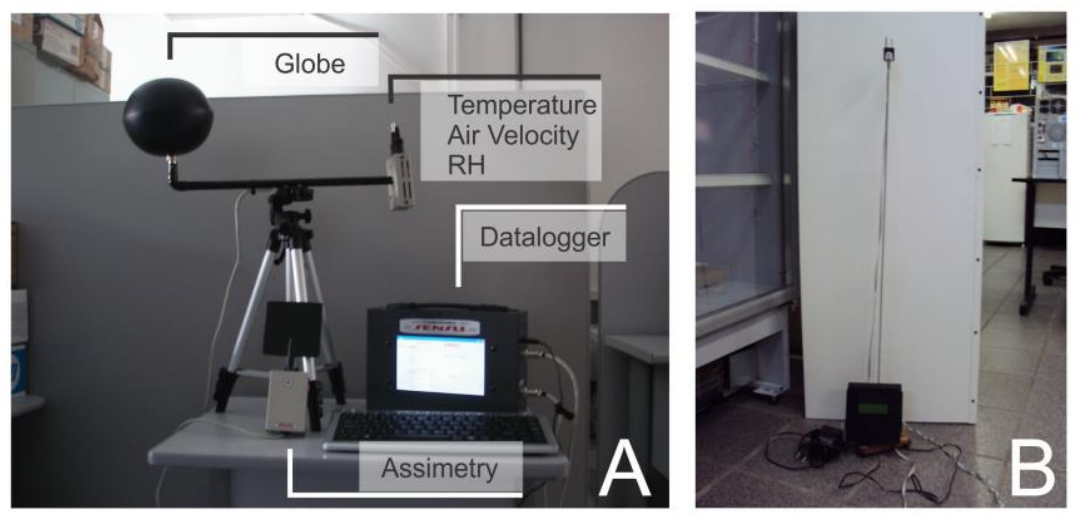

Table 1 -Variation of the outdoor air temperature $\left({ }^{\circ} \mathrm{C}\right)$ during the experiment and standard deviation (SD)

\begin{tabular}{l|c|c|c|c}
\hline & Min. & Max. & Mean $\left({ }^{\circ} \mathbf{C}\right)$ & SD \\
\hline March & 16.9 & 27.4 & 22.9 & 3.2 \\
April & 16.3 & 26.1 & 20.7 & 2.6 \\
May & 16.6 & 23.7 & 20.4 & 2.7 \\
November & 16.8 & 26.4 & 21.5 & 1.1 \\
\hline
\end{tabular}

\section{Subjects}

A total of 2.292 questionnaires were collected during the field campaigns, comprising responses from 544 undergraduate students of the courses: Architecture and Planning, Environmental and Civil Engineering, Sanitary Production, Physics and Mathematics. Among them, 49\% are females and $51 \%$ male. Table 2 depicts more detailed information regarding subjects' anthropometrics. Occupants performed sedentary activities and they wore typical university clothing ensembles varying from 0.22 to 0.89 clo (these values include 0.01 clo estimated for student's chair, which contributes an additional insulation accordingly to table 5.2.2.2C from ASHRAE 55 (AMERICAN..., 2013).

\section{Questionnaire}

During the study, comfort questionnaires were used to record perceptions of thermal comfort on a 'right-here-right-now' basis. Questionnaires focused on subjects' overall thermal comfort and acceptability, prior exposure to air-conditioning, cooling and air movement preferences. The questionnaire was presented in four parts:

(a) subject's anthropometric information and activities;

(b) subjects' cooling preferences, including airconditioning, natural ventilation only and natural ventilation combined with fans. This section also included questions about subjects' prior exposure to air-conditioning, including where they are exposed to air-conditioning (car, home and/or work) and approximate duration of this exposure per day (h);

(c) thermal sensation, preference and acceptability; and

(d) air movement preferences and acceptability.

The questionnaire was based in the ASHRAE 55 Appendix E model (AMERICAN..., 2010) adapted to reach the parameters that this study intended to measure. Table 3 present the questionnaire inquiries related to results of this paper. The content was evaluated and refined though a pilot study, which occurred 6 months before the field campaigns occurred.

\section{Indoor microclimatic instrumentation and measurements protocol}

Air temperature, humidity, globe temperature and air speed were registered with laboratory precision using a microclimatic station (Figure 2a) located closer to the central zone, at $0.60 \mathrm{~m}$ from the floor. Individualized air speed values were also measured using a handheld hot-wire anemometer sensor to measure air movement around the subjects. Figure $2 b$ shows the sensor fixed on a support that allowed for capturing air speed measurements at the subjects working height $(0.60 \mathrm{~m})$ without any disturbance from the researcher's body.

Subjects assessed their immediate indoor environment via a 'right-here-right-now'

10 De Vecchi, R.; Cândido, C. M.; Lamberts, R. 
questionnaire five times throughout the 140minute period (20 minutes intervals; each round of thermal comfort votes lasted less than five minutes) and indoor variables were registered by the microclimatic station every 1-minute. Air velocity values were measured locally in desks with a handheld hot-wire anemometer in order to characterize air speed from fans and air conditioning. During the air velocity measurements, windows were kept closed and ceiling fans always turned on in the higher value (this condition was always kept, and the air conditioner could be controlled - turner on/off - by the occupants). Thus, values were taken in two situations:

(a) when air conditioning was turned on; and (b) off.
This procedure allowed building two air velocity maps: one for analysis when only the fans were ON and other one for analysis with airconditioning and ceiling fans turned ON simultaneously, in both classrooms (see Figure 3, which shows as an example two of the maps with the air speed when the ceiling fans were ON and air conditioners OFF). Subjects began the questionnaire 30 minutes after their arrival in order to avoid any influence from their exposure to thermal transients before getting into the classroom. This period was also used to set-up the indoor microclimatic station and to explain the questionnaire and procedures. Figure 3 shows the occupancy pattern in classrooms during the whole field campaign and the air speed distribution according with the occupied space.

Table 2 -Subjects' anthropometric information

\begin{tabular}{l|c|c|c|c}
\hline & Min. & Max. & Mean & SD \\
\hline Age (years) & 21 & 47 & 21.2 & 3.4 \\
Weight (Kg) & 40 & 116 & 65.7 & 12.4 \\
Heigh (m) & 1.50 & 1.95 & 1.72 & 0.10 \\
\hline
\end{tabular}

Table 3 -Questionnaire inquiries and response options

\begin{tabular}{|c|c|c|}
\hline Question & \multicolumn{2}{|r|}{ Response options } \\
\hline $\begin{array}{l}\text { If you could choose, which of these cooling systems } \\
\text { to improve indoor environments do you prefer? }\end{array}$ & \multicolumn{2}{|c|}{$\begin{array}{ll}\text { - } & \text { Natural Ventilation } \\
\text { - } & \text { Natural Ventilation combined with fans } \\
\text { - } & \text { Air-conditioning }\end{array}$} \\
\hline $\begin{array}{l}\text { Do you normally stay for a long time in air- } \\
\text { conditioning environments? (If so, answer the next } \\
\text { question) }\end{array}$ & \multicolumn{2}{|l|}{$\begin{array}{ll} & \text { Yes } \\
\text { - } & \text { No }\end{array}$} \\
\hline $\begin{array}{l}\text { When and for how long do you used to stay in air- } \\
\text { conditioning environments? }\end{array}$ & $\begin{array}{l}\text { Local } \\
\text { - At home } \\
\text { - In the car } \\
\text { - At work }\end{array}$ & Hour per day: \\
\hline Right now, what is your thermal sensation? & \multicolumn{2}{|c|}{$\begin{array}{ll}\text { - } & \text { Cold }(-3) \\
\text { - } & \text { Cool }(-2) \\
\text { - } & \text { Slightly cool }(-1) \\
\text { - } & \text { Neutral }(0) \\
\text { - } & \text { Slightly warm }(+1) \\
\text { - } & \text { Warm }(+2) \\
\text { - } & \text { Hot }(+3) \\
\end{array}$} \\
\hline Right now, do you prefer to feel: & \multicolumn{2}{|c|}{$\begin{array}{ll}\text { - } & \text { Cooler } \\
\text { - } & \text { No change } \\
\text { - } & \text { Warmer } \\
\end{array}$} \\
\hline $\begin{array}{l}\text { Is the current thermal environment acceptable for } \\
\text { you? }\end{array}$ & \multicolumn{2}{|c|}{$\begin{array}{ll}\text { - } & \text { Acceptable } \\
\text { - } & \text { Unacceptable } \\
\end{array}$} \\
\hline \multirow[t]{2}{*}{$\begin{array}{l}\text { How do you classify the air movement in your } \\
\text { space? }\end{array}$} & Acceptable & $\begin{array}{ll}\text { - } & \text { But too low air speed } \\
\text { - } & \text { Sufficient air speed } \\
\text { - } & \text { But too high air speed }\end{array}$ \\
\hline & Unacceptable & $\begin{array}{ll}- & \text { Too low air speed } \\
\text { - } & \text { Too high air speed }\end{array}$ \\
\hline
\end{tabular}


Figure 3 -Occupancy pattern of the classrooms and air speed distribution

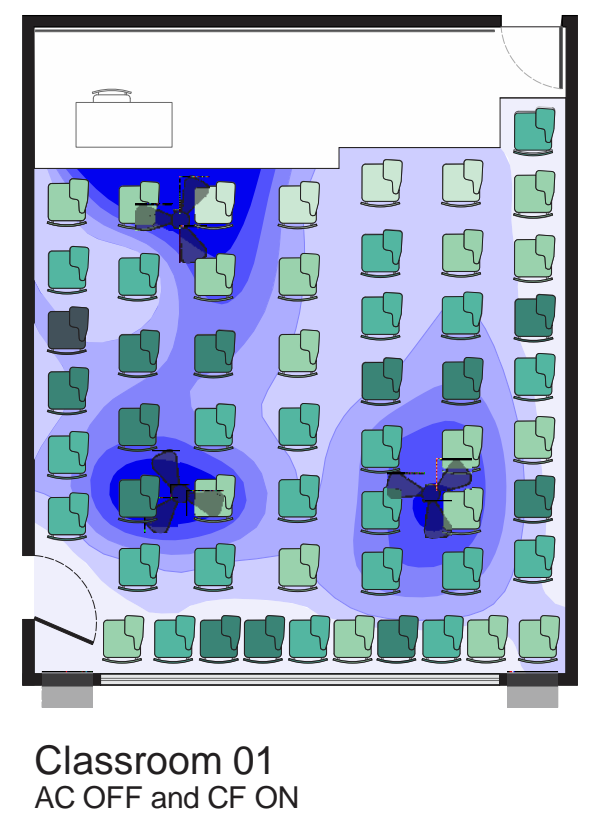

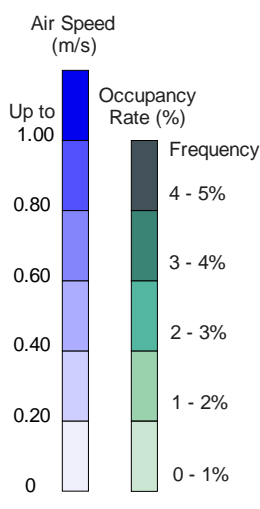

Classroom 02

AC OFF and CF ON
The experiments were performed while the classes happen normally, during the 3 periods of day: morning, afternoon and night. The rooms where the experiments took place were commonly used by students from more than one undergraduate course (classroom 01) and from different periods of the course (classrooms 01 and 02). The researchers did not deliberately influence subjects' activities during the survey; subjects were allowed to free adapt their clothing, but they had to record any changes in their questionnaire. Windows remained closed and the fans remained on throughout the survey to increase air velocity. Cooling devices were accessible (turn on/off the air-conditioning), which occupants could trigger at any time. Students were not allowed to leave the room during the experiments. During the survey, researchers observed everything that happened in the classroom and all changes were immediately reported in the spread sheets.

\section{Data analysis}

Globe temperature was used to calculate the Mean Radiant Temperature (MRT). In addition, Operative Temperature and Standard Effective Temperature $\left(\mathrm{SET}^{1}\right)$ were also calculated with the environmental measurement. Operative temperature was used as an unique value

${ }^{1} \mathrm{SET}$ is defined as "the equivalent dry bulb temperature of an isothermal environment at $50 \% \mathrm{RH}$ in which a subject, while wearing clothing standardized for activity concerned, would have the same heat stress (skin temperature) and thermoregulatory strain (skin wittedness) as in the actual test environment" (AMERICAN..., 2013). representing the entire environment for the air conditioning trigger analysis. The SET index was used in the punctual analysis, varying according to the occupant and their location in the classroom. A subject's Body Mass Index (BMI) was calculated by dividing the individual's body mass by the square of his or their height. A BMI of 18.5 to 25 indicates a normal weight; a BMI lower than 18.5 were classified as underweight, while a number above 25 were classified as overweight.

The database collected and calculated during the experiment were processed and organized into spreadsheets, crossing referencing what was measured with the occupant's responses.

\section{Results and discussion}

In order to analyse the impact of prior exposure to air-conditioning environments on subject's thermal sensation, the questionnaire directly asked subjects to (1) indicate whether or not they are exposed to AC daily and if, yes (2) estimate how many hours a day they are exposed to $\mathrm{AC}$ environments and (3) where they are exposed to such static conditions (i.e., car, home and work). The split between the two groups considering question 1 is similar: $53 \%$ of occupants declared being exposed to AC environments daily and $47 \%$ of occupants declared not being exposed to AC daily. Figure 4 shows that most occupants are exposed to AC while they are at work $(4.5 \mathrm{~h} /$ day $)$, followed by their home (4.4 h/day) and their cars $(1.3 \mathrm{~h} /$ day $)$.

12 De Vecchi, R.; Cândido, C. M.; Lamberts, R. 
Figure 4 - Place and duration of exposure to air conditioning

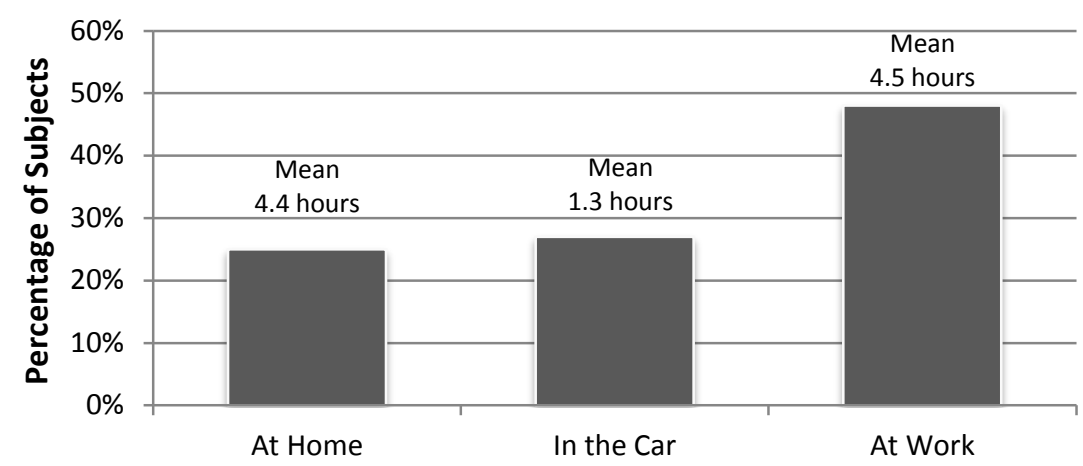

\section{Occupant's thermal sensation, preference and acceptability}

The third section of the questionnaire focused on thermal sensation, preference and acceptability. Table 4 shows the thermal sensation responses grouped by cold discomfort $(-3,-2)$, thermal comfort $(-1,0$ and +1$)$ and hot discomfort $(+2,+3)$, divided into the two categories: with and without prior exposure to air conditioning environments. Analysing the results, no significant differences were observed between the two categories, which confirms previous studies by Cândido et al. (2010). Although, in previous work the authors conducted the experiment in a hotter climate region, and even so, the thermal sensation results are quite similar. Table 4 describes the thermal sensation responses concentrated within the three middle categories of the seven-point scale: 'slightly warm', 'neutral' and 'slightly cool'. There was a slight tendency for users without prior AC exposure to respond that they were cold in the moment, and a slight tendency towards heat from the group with previous exposure.

In contrast with thermal sensation responses, thermal acceptability votes presented a significant difference based on subjects' prior exposure to $\mathrm{AC}$, and these results can be seen in Figure 5. Subjects frequently exposed to AC environments presented less tolerance to warmer temperatures and their thermal acceptability decreased consistently when SET increased from 19 to $25^{\circ} \mathrm{C}$. For this same group, the biggest difference in thermal acceptability can be identified when SET values reached 25 or $26^{\circ} \mathrm{C}$, with the percentages of subjects voting as 'unacceptable' being 30 and $65 \%$, respectively (Figure 5a). Subjects without prior exposure to AC also showed a decrease on their thermal acceptability responses when SET values increased (see Figure 5b). However, the percentage of subjects without prior exposure classifying their indoor environment as 'unacceptable' was below $30 \%$ when SET temperatures reached 25 or $26^{\circ} \mathrm{C}$. These values are considerably inferior when compared to those found for occupants with prior exposure to AC. When matched, results from Figures $5 \mathrm{a}$ and $5 \mathrm{~b}$ suggest that subjects' prior exposure to AC may interfere with occupants' tolerance of warmer temperatures.

Thermal preference responses may shed some light on the thermal acceptability differences noted above. Results suggest that those occupants who responded with 'unacceptable' on the thermal acceptability scale would also prefer to be 'cooler' at the moment of the survey (see Figure 6). The main difference noticed between the groups was (1) the number of subjects with a history of prior exposure to AC preferring to be 'cooler' was larger than the subjects without exposure to AC $(96 \%$ and $70 \%$, respectively) and (2) none of the subjects with a history of exposure to AC responded to 'no change' as their preference. In contrast, only $20 \%$ of subjects without a history of prior exposure to AC responded that 'no change' was their preference (Figure 6b). These results highlight the effects of prior AC exposure on subjects' tolerance to warmer temperature conditions.

\section{Occupants' cooling preferences}

Occupants were asked to indicate which cooling environment they would prefer to be in at specific points in time during the survey. Subjects could choose between three options: air-conditioning, natural ventilation or natural ventilation combined with fans. Most subjects with a history of AC exposure selected the current environment (AC) (54\%) as depicted on Figure 7a. For this same group, only $20 \%$ preferred natural ventilation and $26 \%$ voted for the combination of natural ventilation and fans. Figure $7 \mathrm{~b}$ shows percentages for cooling preferences for subjects without exposure to AC. For this group, the majority of subjects indicated 'natural ventilation' (48\%) as their cooling environment of choice. Approximately $28 \%$ preferred a combination of 
'natural ventilation and fans' and only a minority of subjects $(24 \%)$ declared 'air-conditioning' as their preferred cooling environment. These results are also consistent with the experiments of Cândido et al. (2010), and reinforce the "thermal history" factor on the subjects preferences.

Table 4 -Subjects overall thermal sensation votes grouped by cold discomfort $(-3,-2)$, thermal neutrality $(-1,0$ and +1$)$ and hot discomfort $(+3,+2)$ for those occupants with and without prior exposure

\begin{tabular}{c|c|c|c|c|c}
\hline & $\begin{array}{c}\text { Cold } \\
\text { Discomfort }\end{array}$ & $\begin{array}{c}\text { Thermal } \\
\text { Neutrality }\end{array}$ & $\begin{array}{c}\text { Hot } \\
\text { Discomfort }\end{array}$ & $\begin{array}{c}\text { SET } \\
\text { (average) }\end{array}$ & $\begin{array}{c}\text { Votes } \\
\text { (Total) }\end{array}$ \\
\hline With Prior Exposure & $1 \%$ & $86 \%$ & $13 \%$ & 22.2 & 1.206 \\
Without Prior Exposure & $7 \%$ & $87 \%$ & $6 \%$ & 22.4 & 1.086 \\
\hline
\end{tabular}

Figure 5 - Occupants' thermal acceptability votes distribution for subjects (a) with and (b) without prior exposure to air conditioning

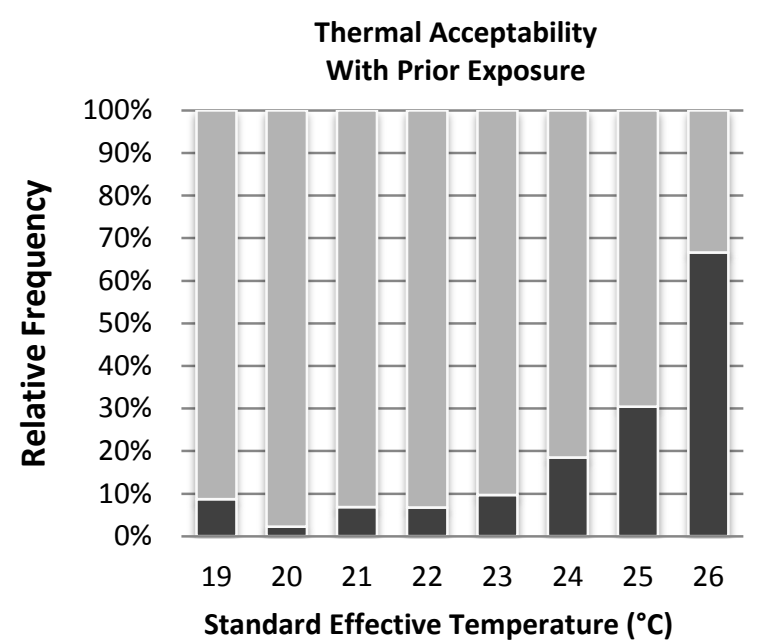

(a)

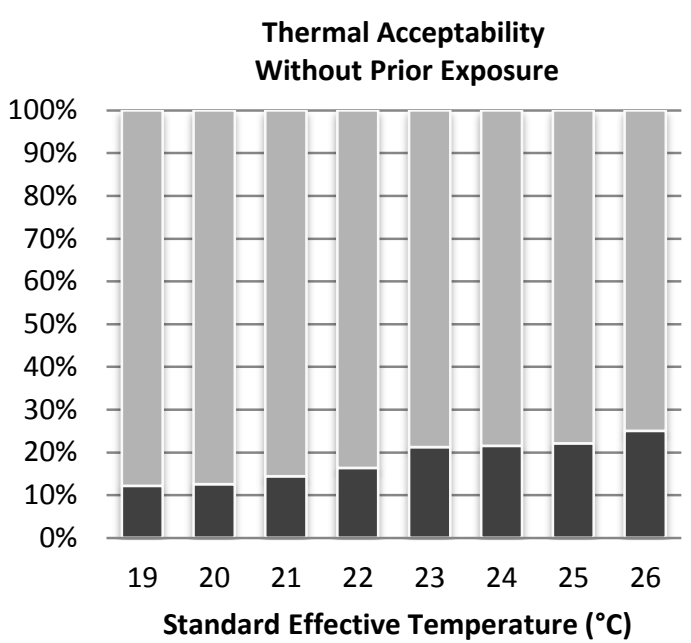

(b)

Unacceptable Acceptable

Figure 6 - Occupants' thermal preference for those voting as "unacceptable" for their thermal acceptability. Subjects with (a) and without (b) prior exposure to air-conditioning

\section{Thermal Preference \\ With Prior Exposure}

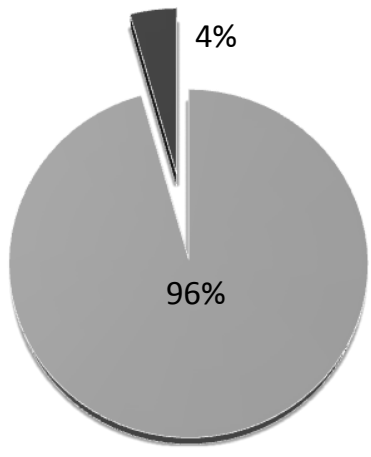

(a)
Thermal Preference Without Prior Exposure

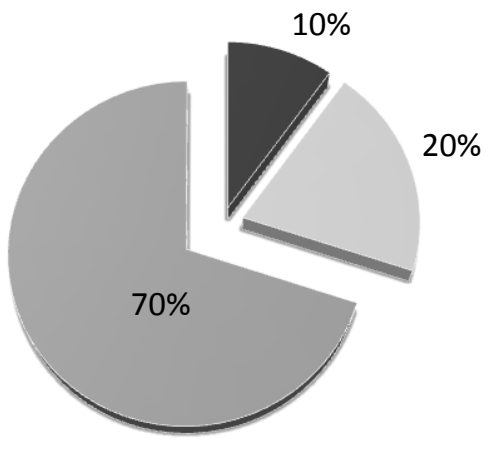

(b)

Want warmer No change Want cooler

14 De Vecchi, R.; Cândido, C. M.; Lamberts, R. 
Figure 7 - Cooling preferences for subjects (a) with and b) without prior exposure to air conditioning environments

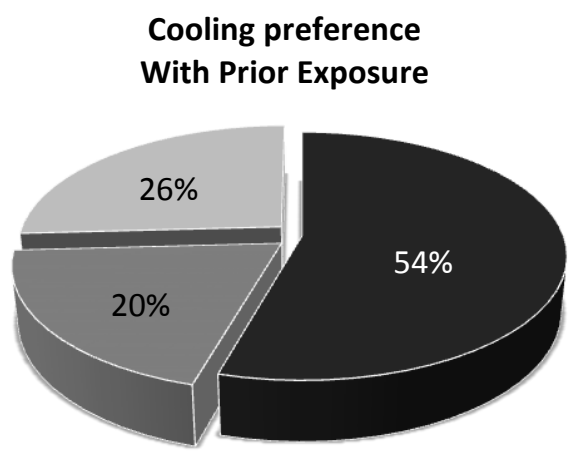

(a)

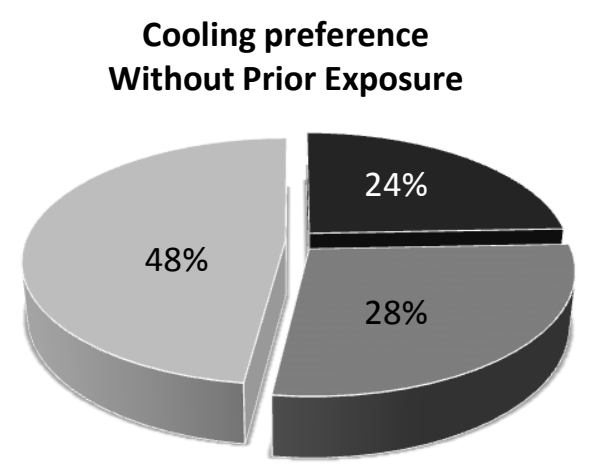

(b)

Air Conditioning

Natural Ventilation

Natural Vent. With Fans

The occupants with prior AC exposure were asked about the amount of time they usually spend in AC environment (namely: the classroom, in the car, workstation or residence). The responses showed a direct correlation between the numbers of hours that subjects were exposed to $\mathrm{AC}$ environments and their cooling preference strategy (Figure 8). The group exposed for long periods to AC environments (above $8 \mathrm{~h}$ ) tended to prefer the AC environment in most cases (over 60\%), as would subjects with fewer than 4 hours of AC exposure (42\%).

Throughout the field studies, subjects turned on the air conditioning on eight different occasions. For each of these occurrences, the mean operative temperature was calculated as an average of the twenty minute readings taken just before subjects turned the split system on. Figure 9 shows this AC 'trigger' operative temperature, running mean temperatures and maximum outdoor air temperature during field studies. Based on Figure 9 it is possible to notice that (1) AC's trigger temperatures fluctuated closely to the maximum external temperature and (2) the AC's trigger temperature ranged from 22 to $28^{\circ} \mathrm{C}$, with $25^{\circ} \mathrm{C}$ being the average temperature when occupants switched the AC unit on. These results suggest the potential to implement temperature fluctuations indoors as predicted by the adaptive model when designing and operating mixed-mode buildings in warm climates.

\section{Gender}

When analysing subjects' cooling preferences, significant differences came to light based on gender (see Figure 10). The percentage of male subjects indicating $\mathrm{AC}$ as their cooling preference was significantly higher $(75 \%)$ than female subjects $(21 \%)$. In contrast, female subjects indicated 'natural ventilation' or 'natural ventilation with fans' as their cooling preference of choice in most occasions (62\% and 60\%). Such 'rejection' to air-conditioning from female subjects found in this study is supported by previous findings (CHOI; AZIZ; LOFTNESS, 2010), where female subjects were more susceptible to feel cold, and consequently, tended to prefer higher temperatures than male subjects. Garment layers and local discomfort may also influence such gender differences but they were not investigated in this study.

\section{Body weight}

Subjects' BMI calculations were classified into 3 categories: 'underweight', 'normal' or 'overweight'. Figure 11 shows that subjects' falling within the overweight category presented a slightly higher preference for AC (43\%) when compared to those subjects' classified as being underweight $(27 \%)$. This difference was slightly smaller when cooling preference responses from overweight subjects were compared against those received from subjects with normal BMI values (39\%). There are numerous potential explanation for the underlining factors of BMI and human thermal comfort and research findings from the human physiology field may bring some light into this discussion by starting to link body mass and thermal comfort (VAN MARKEN LICHTENBELT; KINGMA, 2013). However, more research should be done on this specific area as to date; results indicate that this topic is still in its infancy. 
Figure 8 - Cooling preference binned by the daily hours of prior exposure to air conditioning

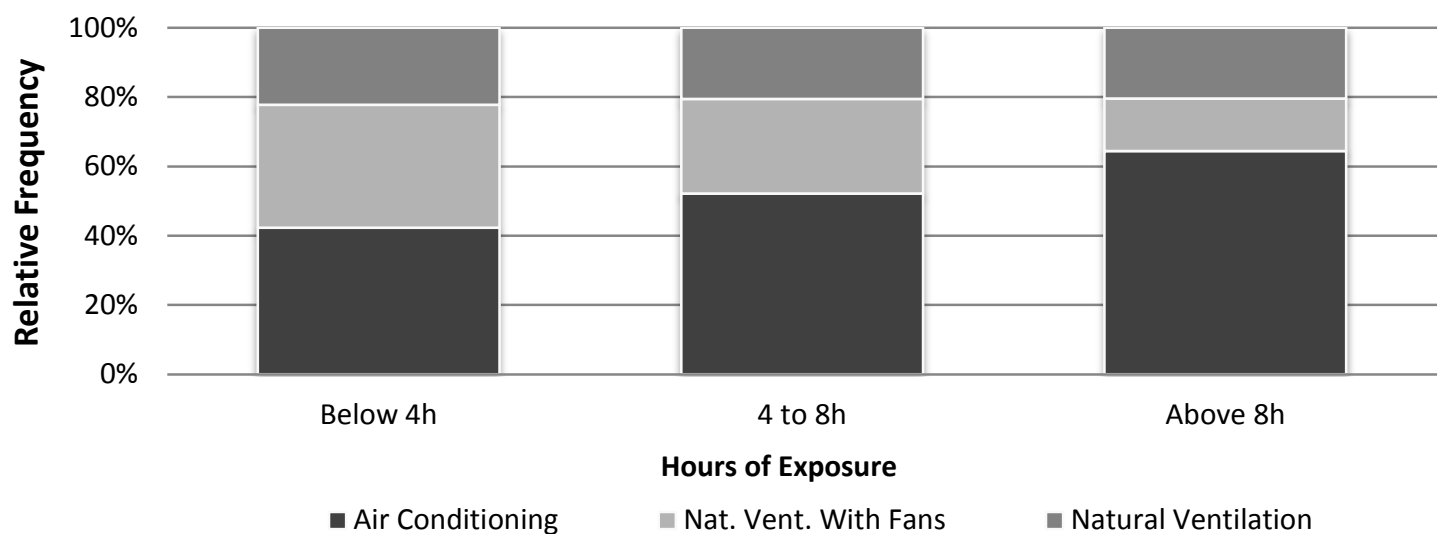

Figure 9 - Observed AC's 'trigger' operative temperatures during field studies

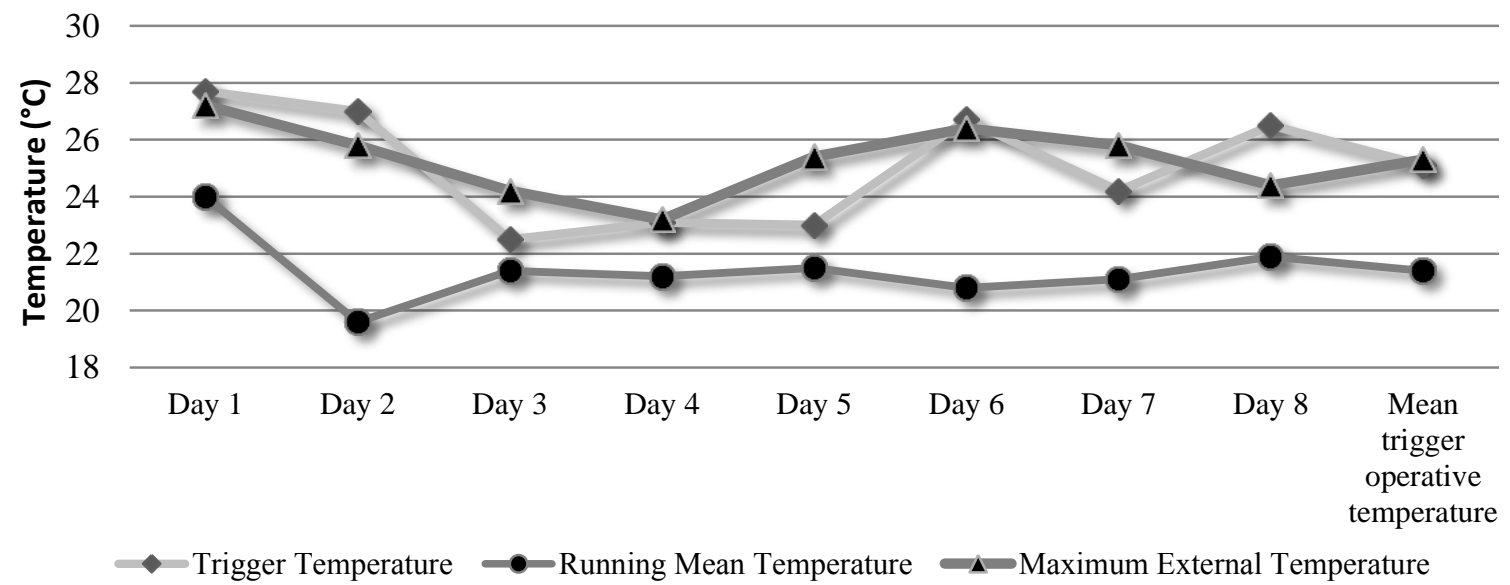

Figure 10 - Occupants' cooling preference binned by gender

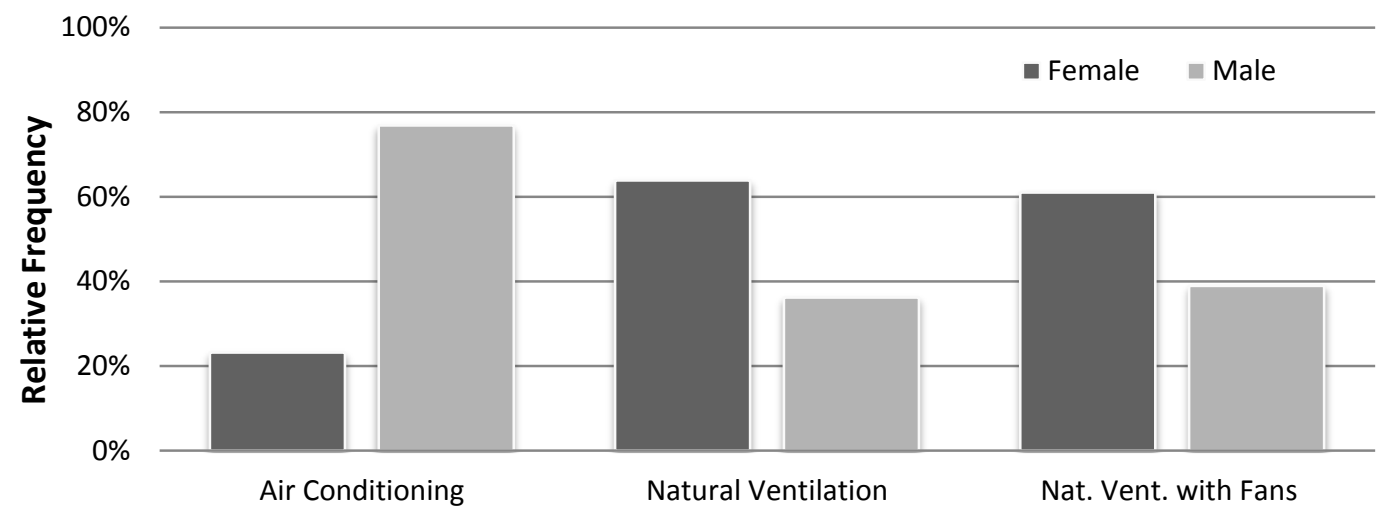

16 De Vecchi, R.; Cândido, C. M.; Lamberts, R. 
Figure 11 - Occupants' cooling preference binned by the body mass index

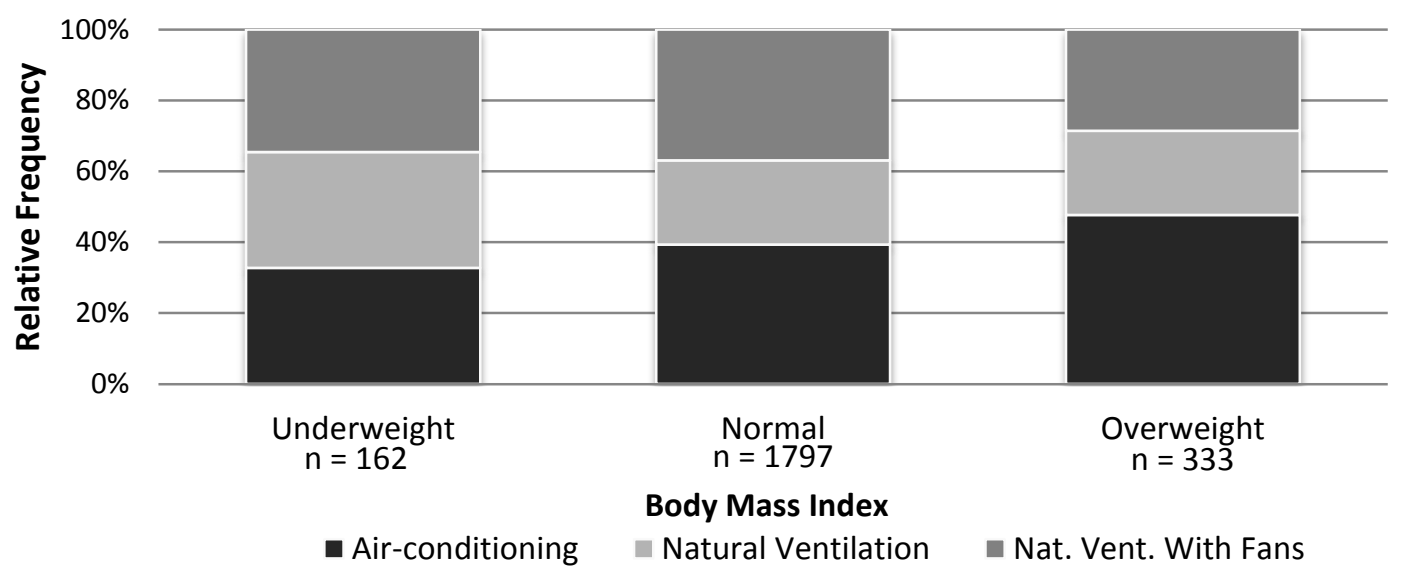

Figure 12 - Thermal acceptability and the relationship with air speed

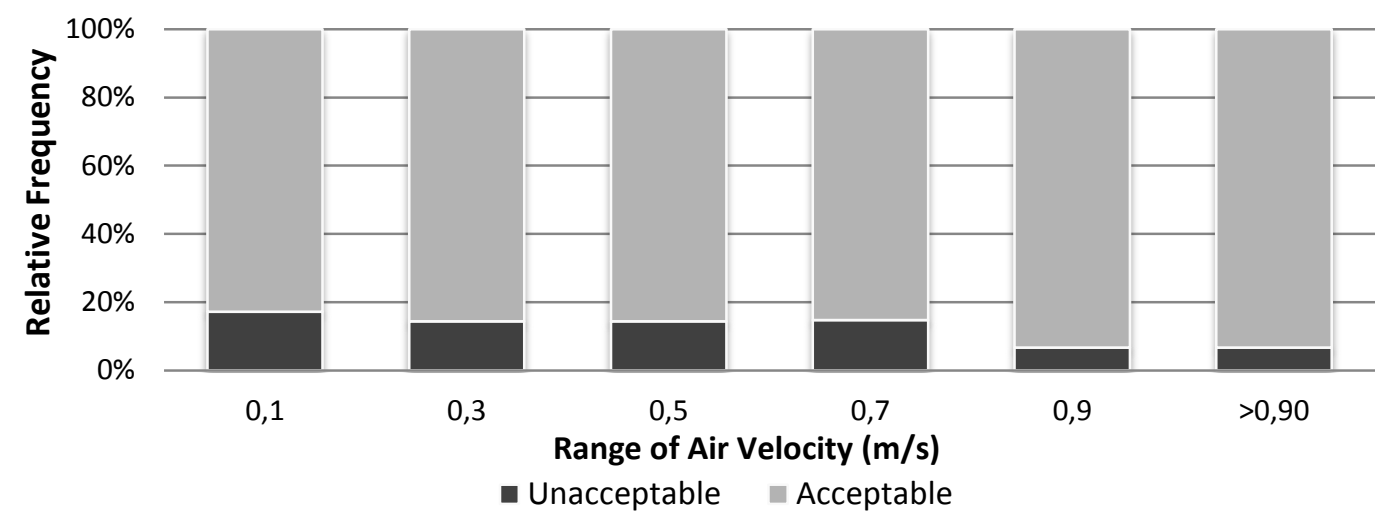

Figure 13 - Air velocity acceptability between the two groups: (a) with and (b) without prior exposure to air conditioning

\section{Air Velocity Acceptability} With Prior Exposure

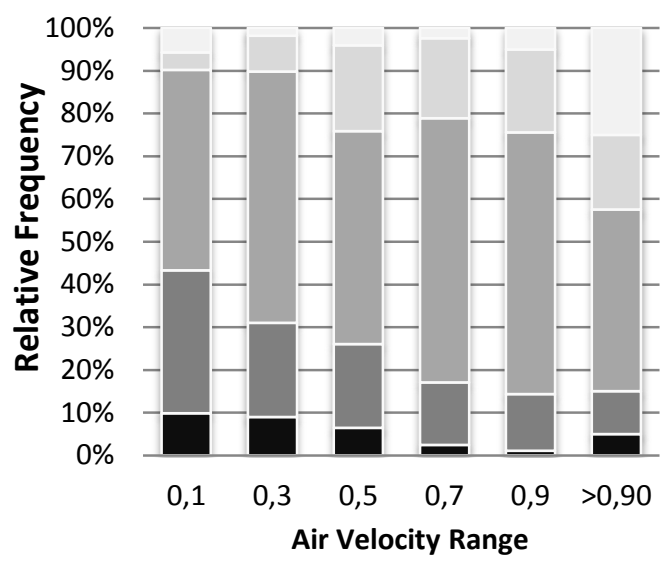

(a)

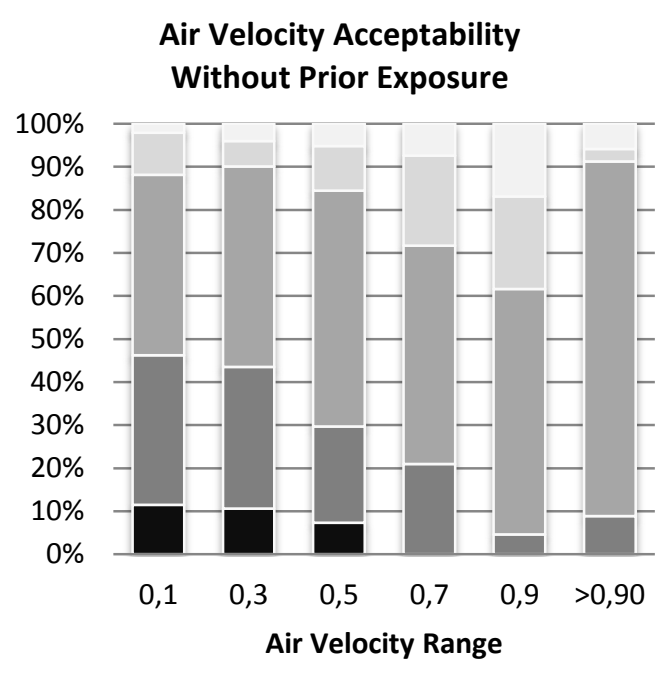

(b)

\footnotetext{
Too low air speed $\quad$ Too low air speed $\quad$ Sufficient air speed $\square$ Too much air speed $\square$ Too much air speed
Unacceptable Scale
} 


\section{Occupants' air movement acceptability results}

Occupants were also asked about their acceptability of the air velocity at specific points in time during the survey. Occupants were asked to (1) select if the air velocity was 'acceptable' or 'unacceptable' and then (2) indicate if the air velocity was 'too low', 'too high' or 'sufficient'. Results were binned in a $0.20 \mathrm{~m} / \mathrm{s}$ range as showed in Figure 12, where the highest percentage of occupants classifying thermal environment as 'unacceptable' occurred in the group of air velocity classified as $0.10 \mathrm{~m} / \mathrm{s}$, while the lowest percentage occurred when this value increase to $0.90 \mathrm{~m} / \mathrm{s}$ or above. These results indicate the importance of providing higher air velocity values to building occupants in warm climates.

Air velocity acceptability results were also broken down into two groups for analysis based on occupants' prior exposure to AC (Figure 13). The highest percentage of occupants responding that air velocity was 'sufficient' occurred when air velocity ranged from 0.7 to $0.9 \mathrm{~m} / \mathrm{s}$ on average. For those occupants without a history of exposure to $\mathrm{AC}$, air velocity acceptability results indicate a preference for slightly higher values of air speed, with most of this sample classifying air velocity as 'sufficient' when the average was around $0.90 \mathrm{~m} / \mathrm{s}$.

\section{Conclusions}

This paper presented the connection between prior exposure to air-conditioning spaces and its implications on occupants' overall thermal comfort in mixed-mode buildings. Occupants' history of prior exposure to air conditioning influenced their overall thermal comfort and cooling preferences. Such influence would not be revealed solely based on thermal sensation responses, since no significant differences were found between occupants' with and without prior exposure to air conditioning. Nevertheless, the groups showed significant differences when acceptability and thermal preference were analysed; this fact suggests that subjects' prior AC exposure may interfere with an occupants' tolerance for warmer temperatures.

Besides the low tolerance linked to higher temperatures, most subjects with a history of AC exposure selected $\mathrm{AC}$ as the cooling system preferred during the survey. Such a preference shows a direct correlation with the number of hours that subjects were exposed to these environments. The longer time a user spends in air-conditioned environments, the greater the probability to prefer identical cooling strategies.
Additionally, significant differences related to subjects' thermal sensation and cooling preferences were found between male and female subjects; body weight also contributed to preferential differences. The results show that males are more susceptive to prefer AC systems than female subjects; similarly occupants classified as "overweight" demonstrate a higher preference to air-conditioned environments when compared with "normal" and "underweight" occupants.

This paper indicates that when occupants are exposed to mixed-mode buildings, there is a significant potential to implement temperature fluctuations indoors as predicted by the adaptive model when designing and operating buildings in warm climates. The air velocity increase associated with air conditioning should be encouraged in order to meet occupants rising comfort expectations and raise the set point temperature, resulting in energy saving. Whether such air conditioning 'addiction' would be reversible, is yet to be understood and more research is necessary to shed some light on how 'acclimatize' such 'air-conditioning addicts' are to warmer indoor environments without compromising their thermal acceptability.

\section{References}

AL-AJMI, F. F.; LOVEDAY, D. Indoor Thermal Conditions and Thermal Comfort in AirConditioned Domestic Buildings in the Dry-Desert Climate of Kuwait. Building and Environment, v. 45, n. 3, p. 704-710, 2010.

\section{AMERICAN SOCIETY OF HEATING REFRIGERATING AND AIR-CONDITIONING} ENGINEERS. Standard 55: thermal environmental conditions for human occupancy. Atlanta, Georgia, 2010.

\section{AMERICAN SOCIETY OF HEATING REFRIGERATING AND AIR-CONDITIONING} ENGINEERS. Standard 55: thermal environmental conditions for human occupancy. Atlanta, Georgia, 2013.

BOERSTRA, A. C. Personal Control In Future Thermal Comfort Standards? In: WINDSOR CONFERENCE: ADAPTING TO CHANGE: NEW THINKING ON COMFORT, 6., Windsor, 2010. Proceedings... Windsor, UK, 2010.

BRAGER, G.; BAKER, L. Occupant Satisfaction in Mixed-Mode Buildings. Building Research \& Information, v. 37, n. 4, p. 369-380, 2009. 
CÂNDIDO, C. et al. Cooling Exposure in Hot Humid Climates: are occupants "addicted"? Architectural Science Review, v. 53, n. 1, p. 5964, 2010.

CANDIDO, C.; DEAR, R. DE. From Thermal Boredom to Thermal Pleasure: a brief literature review. Ambiente Construído, Porto Alegre, v. 12, n. 1, p. 81-90, jan./mar. 2012.

CAO, B. et al. Field Study of Human Thermal Comfort and Thermal Adaptability During the Summer and Winter in Beijing. Energy and Buildings, v. 43, n. 5, p. 1051-1056, 2011.

CHOI, J.; AZIZ, A.; LOFTNESS, V. Investigation on the Impacts of Different Genders and Ages on Satisfaction With Thermal Environments in Office Buildings. Building and Environment, v. 45, n. 6, p. 1529-1535, jun. 2010.

CHOW, T. et al. Thermal Sensation of Hong Kong People With Increased Air Speed, Temperature and Humidity in Air-Conditioned Environment. Building and Environment, v. 45, n. 10, p. 2177 2183, 2010.

CHUN, C. et al. Thermal Diary: connecting temperature history to indoor comfort. Building and Environment, v. 43, n. 5, p. 877-885, 2008.

DE DEAR, R. Revisiting an Old Hypothesis of Human Thermal Perception: alliesthesia. Building Research \& Information, v. 39, n. 2, p. 108-117, abr. 2011.

DE DEAR, R.; BRAGER, G. Thermal Comfort in Naturally Ventilated Buildings: revisions to ASHRAE Standard 55. Energy and Buildings, v. 34, n. 6, p. 549-561, 2002.

DE DEAR, R.; BRAGER, G.; COOPER, D. Developing an Adaptive Model of Thermal Comfort and Preference: final report on ASHRAE RP - 884. Sydney: MRL, 1997.

DE DEAR, R. J.; AULICIEMS, A. Air Conditioning in Australia - II - user attitudes. Architectural Science Review, v. 31, p. 19-27, 1988.

FANGER, P. O. Thermal Comfort: analysis and applications in environmental engineering. Copenhagen: Darlish Techinical Press, 1970.

FERIADI, H.; WONG, N. H. Thermal Comfort For Naturally Ventilated Houses in Indonesia. Energy and Buildings, v. 36, n. 7, p. 614-626, 2004.

GOULART, S.; LAMBERTS, R.; FIRMINO, S. Dados Climáticos Para Projeto e Avaliação Energética de Edificações Para 14 Cidades Brasileiras. Florianópolis: PROCEL/Núcleo de Pesquisa em Construção Civil da UFSC, 1998.
HUIZENGA, C.; ZHANG, H.; ARENS, E. A Model of Human Physiology and Comfort For Assessing Complex Thermal Environments. Building and Environment, v. 36, p. 691-699, 2001.

HUMPHREYS, M.; NICOL, F. The Validity of ISO-PMV For Predicting Comfort Votes in EveryDay Thermal Environments. Energy and Buildings, v. 34, n. 6, p. 667-684, 2010.

INDRAGANTI, M.; OOKA, R.; RIJAL, H. B. Thermal Comfort in Offices in Summer: findings from a field study under the "setsuden" conditions in Tokyo, Japan. Building and Environment, v. 61, p. 114-132, mar. 2013.

JOHNSON, F. et al. Could Increase Time Spent in a Thermal Comfort Zone Contribute to Population Increases in Obesity? Obesity Reviews : an official journal of the International Association for the Study of Obesity, v. 12, p. 543-551, 2011.

KEITH, S. W. et al. Putative Contributors to the Secular Increase in Obesity: exploring the roads less traveled. Internacional Journal of Obesity, v. 30, n. 11, p. 1585-1594, 2006.

KWOK, A. G.; RAJKOVICH, N. B. Addressing Climate Change in Comfort Standards. Building and Environment, v. 45, n. 1, p. 18-22, jan. 2010.

LINDEN, K. VAN DER; LOOMANS, M.; HENSEN, J. Adaptive Thermal Comfort Explained by PMV. In: INTERNATIONAL CONFERENCE ON INDOOR AIR QUALITY AND CLIMATE, 11., Copenhagen, 2008. Proceedings... Copenhagen, 2008.

MORS, S. et al. Adaptive Thermal Comfort in Primary School Classrooms: creating and validating PMV-based comfort charts. Building and Environment, v. 46, n. 12, p. 2454-2461, 2011.

PARKINSON, T.; DE DEAR, R.; CÂNDIDO, C. Perception of Transient Thermal Environments: pleasure and alliesthesia. In: Windsor Conference: The changing context of comfort in an unpredictable world, 7., Windsor, UK, 2012. Proceedings... Windsor, UK, 2012.

PEREIRA, E. B. et al. Atlas Brasileiro de Energia Solar. São José dos Campos : INPE, 2006.

TANABE, S. et al. Evaluation of Thermal Comfort Using Combined Multi-Node Thermoregulation $(65 \mathrm{MN})$ and Radiation Models and Computational Fluid Dynamics (CFD). Energy and Buildings, v. 34, n. 6, p. 637-646, 2002. 
VAN MARKEN LICHTENBELT, W. D.; SCHRAUWEN, P.; WESTERTERP-PLANTEGA, M. S. Effect of Mild Cold on Metabolic and Insulative Adaptation in Man. Journal of Thermal Biology, v. 26, n. 4-5, p. 449-453, 2001.

VAN MARKEN LICHTENBELT, W.; KINGMA, B. Building and Occupant Energetics: a physiological hypothesis. Architectural Science Review, v. 56, n. 1, p. 48-53, 2013.

ZHANG, Y. et al. Thermal Comfort in Naturally Ventilated Buildings in Hot-Humid Area of China. Building and Environment, v. 45, n. 11, p. 2562 2570, 2010.

\section{Acknowledgments}

This project was supported by $\mathrm{CNPq}$ - National Counsel of Technological and Scientific Development. We would like to thank to the Department of Architecture and Urbanism of Federal University of Santa Catarina, which made the realization of the field experiment possible. Special thanks also to all subjects whom agreed to participate during these experiments.

Renata De Vecchi

Departamento de Engenharia Civil | Universidade Federal de Santa Catarina | Rua João Pio Duarte Silva, 241 - Córrego Grande, Campus Universitário | Florianópolis - SC - Brasil | Caixa Postal 476 | CEP 88040-900 | Tel.: (48) 3271-5185 | E-mail: redevecchi@gmail.com

\section{Christhina Maria Cândido}

Design and Planning, Faculty of Architecture | The University of Sydney | Wilkinson bd (G04), Room 590, Darlington | Sydney - Austrália | 2006 | Tel.: +(2) 9351-3206 | E-mail: christhina.candido@sydney.edu.au

\section{Roberto Lamberts}

Departamento de Engenharia Civil, Centro Tecnológico | Universidade Federal de Santa Catarina | Tel.: (48) 3721 -2390 |

E-mail: roberto.lamberts@ufsc.br

\section{Revista Ambiente Construído}

Associação Nacional de Tecnologia do Ambiente Construído

Av. Osvaldo Aranha, $99-3^{\circ}$ andar, Centro

Porto Alegre - RS - Brasil

CEP $90035-190$

Telefone: +55 (51) 3308-4084

Fax: +55 (51) 3308-4054

www.seer.ufrgs.br/ambienteconstruido

E-mail: ambienteconstruido@ufrgs.br

20 De Vecchi, R.; Cândido, C. M.; Lamberts, R. 